\title{
Factors Influencing The Inflation Of Indonesia In Islamic Perspectives
}

\author{
Anton Bawono
}

Faculty of Islamic Economics and Business IAIN Salatiga, Indonesia

Email korenpondensi: alfathbawono@gmail.com

The purpose of the study is to identify the factors that influence inflation, using secondary data from 1987 to 2017. Methods for analyzing data using multiple linear regression. The result of the study shows that money supply has a positive and significant effect on inflation while economic growth has a negative and significant effect on inflation occurs in Indonesia. While interest rates do not have an influence on inflation occurs in Indonesia

Keywords: Inflation, Money supply, Interest rates, Economic growth

\begin{abstract}
Abstrak
Tujuan penelitian untuk mengidentifikasi faktor-faktor yang berpengaruh terhadap inflasi, dengan menggunakan data sekunder dari tahun 1987-2017. Metode untuk menganalisis data dengan menggunakan regresi linear berganda. Hasil penelitian menunjukkan bahwa uang beredar mempunyai pengaruh positif terhadap inflasi, sedangkan pertumbuhan ekonomi mempunyai pengaruh negatif terhadap terhadap inflasi yang terjadi di indonesia. Sementara suku bunga tidak mempunyai pengaruh terhadap inflasi yang terjadi di indonesia.
\end{abstract}

Kata kunci: Inflasi, Uang beredar, Suku bunga, Pertumbuhan ekonomi

Saran sitasi: Bawono, A. (2019). Factors Influencing The Inflation of Indonesia In Islamic Perspectives. Jurnal Ilmiah Ekonomi Islam, 5(2), 81-88. Doi:http://dx.doi.org/10.29040/jiei.v5i2.579

DOI: http://dx.doi.org/10.29040/jiei.v5i2.579

\section{Introduction}

Price stability is very important in the economy and is one key to success in the development process. It relates this to the aim of economic development to achieve prosperity, which is characterized by increasing a country's real per capita income in the long run (Arsyad, 2010). In fact, almost all countries, especially developing countries, face the problem of price stability or inflation, which increase will have an adverse effect on economic activity. Both from the standpoint of conventional economics and from the standpoint of Islamic economics.
The increase in inflation concerns the financial or income of the people. Increasing of inflation makes purchasing power low, so that people need more money or income to get goods and services. In the banking sector, inflation will affect to the low interest in saving because of reduced margins. While in the merchant or producer sector, it causes inappropriate pricing. Another impact of high inflation causes an increase in unemployment because of the termination of production activities. In an economy, the occurrence of inflation has several impacts; 1) Inflation can cause income inequality, which will affect the economic welfare of 
community members; 2) inflation can cause a decrease in economic efficiency, because there is a transfer of labor-intensive investments to capital intensive so as to increase the unemployment rate; 3 ) inflation can also cause changes in output and employment (Nanga, 2005).

Inflation in according to Islamic economics has a terrible impact on the economy; 1) interfere with the function of money; 2) weaken all savings and attitudes to save; 3) increase the tendency to shop; 4) investment in unproductive things (Awaluddin, 2017; Parakassi, 2018). Other impacts related to accounting are; 1) on methods for asset assessment; 2) the maintenance of real capital (inflationary); and 3) corrective correction and reconciliation needed to get timely comparison requirements (Karim, 2016).

Islamic economist Taqiuddin Ahmad ibn AlMaqrizi classifies two categories of causes of inflation, namely natural inflation and human error inflation. Natural inflation is inflation caused by natural causes, while human error inflation is inflation caused by errors from the human resource itself (Karim, 2016). There are three groups of human error inflation, namely; 1) corruption and bad administration; 2) excessive tax; and 3) excessive seignorage.

Indonesia as a middle-income country in developing its economy very depends on the world economy. This condition places Indonesia to face economic problems both from inside and outside. While problems arise like slowed economic growth, the movement of the money supply increases, and the increasing interest rates cause increases in goods prices or inflation (Frisdiantara, Mukhklis, \& Si, 2016; Mankiw, 2007; Yodiatmaja, 2012). These conditions will become obstacles in the process of economic development which has an orientation to the welfare of the community. The conditions for the outgrowth of inflation Indonesia from 1987 to 2017 are as shown in Figure 1.

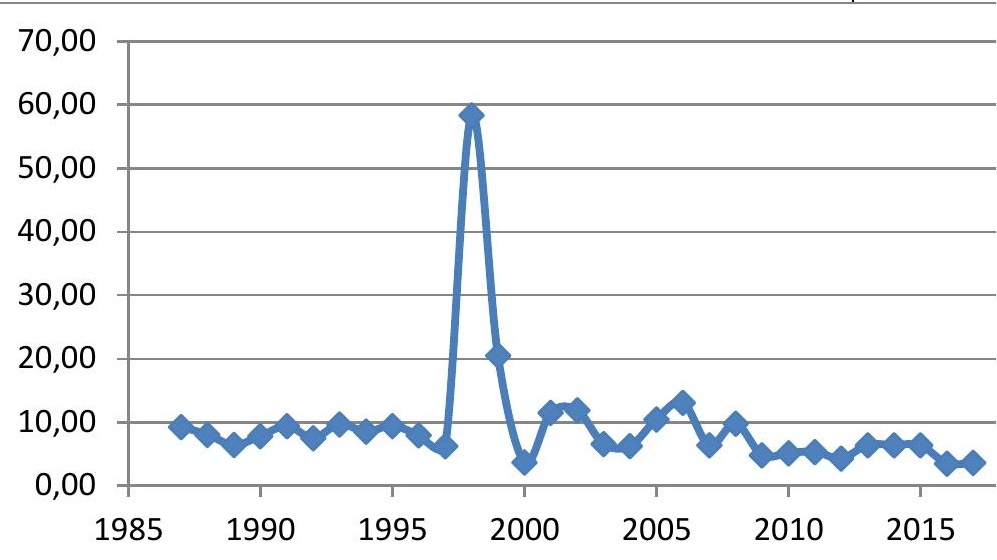

Figure 1. Development of Indonesia Inflation 1987-2017

Source: World Bank (2018)

Based on Figure 1 shows that the inflation phenomenon in Indonesia has fluctuations from year to year. The occurrence of fluctuations in each year needs to have studied, because the impact related to economic development in Indonesia both indirectly and directly. Especially the impact caused after the crisis or conditions of high inflation.

The results of empirical studies related about inflation and the numbers of money supply by Nguyen (2015) show that the total of money supply offers (M2) has a significant positive impact on inflation. Besides that Ramady (2009), Salmanpour and Bahloli (2011), Shah, Aleem and Arshed (2014), Denbel, Ayen and Regasa (2016), also shows that an increase in the money supply causes inflation to increase. While the results of Lim and Sek (2015) show that in countries with low inflation, money supply has a negative influence in the long run on inflation.

Economic growth based on empirical studies behaves differently with the money supply and exchange rates. Laryea and Sumaila (2001), Denbel, Ayen and Regasa (2016), Lim and Sek (2015), show economic growth has a negative effect on inflation. Likewise, with the studied by Aurangzeb and Haq (2012), which shows gross domestic production has a negative relationship with inflation. While the results of the study conducted by Salmanpour and Bahloli (2011), show that gross domestic product growth has no effect on the inflation rate. 
The relationship between interest rates and inflation based on the results of an empirical study conducted by Nguyen (2015), showing a statistically significant interest rate on inflation. Meanwhile Olatunji et al. (2010), shows that interest rates negatively affect inflation. Aurangzeb and Haq (2012), show interest rates experience a positive relationship with inflation. Ramady (2009), shows that interest rates are the main cause of inflation rate.

Based on the explanation above there are still differences in research findings both in the money supply, economic growth and interest rates on inflation. This study analyzes the effect of the money supply, economic growth and interest rates on Indonesia's money supply.

\section{Literature Review}

\subsection{Inflation and money supply}

Theory of quantity said that the current money supply determines the price level for the moment. This is partly true: if the nominal interest rate and the level of output declared constant, the price level moves proportionally to the money supply. But the nominal interest rate is not constant: it depends on expected inflation, which in turn depends on the growth of the money supply. The presence of a nominal interest rate in the money demand function produces additional channels for the money supply that affect the price level (Mankiw, 2007).

\subsection{Inflation and Economic Growth}

The economic cycle started from economic development that experiences high output growth (booming/peak) which characterized by high economic growth, broad employment opportunities and controlled inflation. Subsequent developments in the economy experienced a decline in activities characterized by increasingly decreasing levels of economic growth, reduced employment opportunities, and rising inflation. Prolonged conditions will cause an economic situation to experience depression. In this condition the economy will be characterized by a situation where economic growth reaches its lowest rate, unemployment increases and inflation is also out of control (Frisdiantara et al., 2016).

\subsection{Inflation and Interest Rates.}

Interest rates were a measure of the price of resources used by debtors must be paid to creditors. According to Yodiatmaja (2012) the change in interest rates (BI rate) will affect macro variables which ultimately are passed on to inflation. In simple terms, interest rates can be understood as the price of a loan expressed as a percentage of principal per unit of time. The relationship between interest rates and inflation occurs if interest rates are low, which will impact the increasing number of people borrowing money. The result of loans increases consumption increases. The next stage will impact increasing the money supply and ultimately increasing.

\subsection{Empirical Study}

Empirical research related to inflation conducted by Nguyen (2015), shows the amount of money supply (M2) has a significant positive impact on inflation, with the estimated method of the Pooled Mean Group (PMG), while the fiscal deficit, government expenditure and interest rates are significantly statistics on inflation using the Pooled Mean Group method and the General Method of Moment. Olatunji et al. (2010), in his research on factors that influence inflation in Nigeria, showed that interest rates negatively affected inflation.

Denbel, Ayen and Regasa (2016), in his study of the causal relationship presence between inflation and the money supply and between inflation and economic growth in Ethiopia. The results of the research show that there is a twoway long-term causality relationship between inflation and the money supply and one direction from economic growth to inflation. While, in the short term there is a causality between the offering of money supply and economic growth to inflation. In addition, the core of his findings was negative economic growth and significant to the inflation. Ramady (2009), regarding factors influencing inflation in Saudi Arabia. The results 
of empirical studies show that money supply, interest rates and riyal depreciation are the main causes of inflation in Saudi Arabia. Aurangzeb and Haq (2012), in studies of determinants inflation in Pakistan. The results of the study show that gross domestic production is a negative relationship with inflation, while the exchange rate, interest rates, fiscal deficits and unemployment experience a positive relationship with inflation.

Lim and Sek (2015), in his research that examined the factors influence inflation in two groups of countries. The results of the study show that GDP growth and imports of goods and services have a significant long-term impact on inflation in low inflation countries. In addition, that the money offering, national expenditure and GDP growth are the determinant of long-term inflation in inflation in high inflation countries. While in the short term also, there is no significant variable on inflation in high inflation countries. But the money offer, imports of goods and services and GDP growth have a significant relationship with inflation in low inflation countries. Laryea and Sumaila (2001), in its review of the main determinants of inflation both in the long term and in the short term. The result of study shows that in the short term, output and monetary factors (money supply, exchange value) are the main determinants of inflation. While in the long run, parallel exchange rates also play a key role, besides output and money against inflation. Positive coefficients on the exchange rate variable reflect the effect on inflation through trade in goods, especially through imports in the informal sector.

Agusmianata et al. (2018), in their research related to inflation using multiple linear regression analysis shows that there is a significant effect of the money supply on inflation, the interest rate influences inflation and government expenditure influences inflation. Money supply affects most of Indonesia's inflation.

Salmanpour and Bahloli (2011), in their studies of the main factors, that influences inflation in Iran. The results of the study show that effective factors influence inflation rates such as money supply; the exchange rate and growth of gross domestic product simultaneously. Money offer and exchange rate growth on the black market have a positive effect and gross domestic product growth has no effect on the inflation rate.

Shah, Aleem and Arshed (2014), in his research analyzing the factors influence inflation in Pakistan. The results of the study show that durable goods, electricity, imports, natural gas, steel products, capital goods exports, food imports and the government loan sector have affected inflation. The more the government loans, the higher the money supply causes inflation to increase.

Langi (2014), which examined interest rates; amount of money; and the rate of inflation. The method used is the Engle-Granger (ECM-EG) error correction model. The results of the study show that interest rates have a positive effect on inflation, while the money supply rate is not significant for inflation.

Habibi and Hidayat (2017), in their research on inflation in the short and long term, using the error correction model (ECM). The results show that in the long-term variable the interest rate of Bank Indonesia Certificate and the money supply have a significant effect on the inflation rate in Indonesia. While in the short term only the interest rates of Bank Indonesia Certificates have a significant effect on the inflation rate in Indonesia.

\section{Research Methode}

\subsection{Data types and sources}

This study uses secondary data, namely time series data from 1987 to 2017 sourced from the World Bank. These data are inflation (INF), money supply growth (GM2), economic growth (GROWTH), and interest rates (INTER).

\subsection{Variable definition}

Inflation measured by the consumer price index (CPI) which reflects the change in the 
percentage of average costs for goods and services which the value can remain or change at certain intervals (annual) in units of a percent. The money supply measured by the value of the growth in the currency's amount; current account deposits other than those from the central government; check banks and tourists; and other securities such as certificates of deposit and securities, in units of a percent. Economic growth is the percentage level of annual GDP growth at market prices based on constant prices, in units of a percent. The interest rate is the price of loans expressed as a percentage of principal per unit of time, in percent units.

\subsection{Method of Data Analysis}

The method of data analysis in this study uses a multiple linear regression analysis model. Regression analysis is the study of the dependence of one dependent variable on one or more other variables (Gujarati \& Porter, 2010). The model of the equation in this study is:

Inft $=\alpha+\beta 1$ GM2 $\mathrm{t}+\beta 2$ GROWTHt $+\beta 3$ INTER $\mathrm{t}+\mathrm{utt}$

However, before it uses the data for interpretation, it is necessary to do a classic assumption test which includes tests of normality, multicollinearity, heteroscedasticity and autocorrelation, and linearity. Furthermore, a significance test carried out which includes:

\subsection{F Statistics Test}

$\mathrm{F}$ test shows whether all the independent variables included in the model have a simultaneous effect on the dependent variable (Ghozali, 2011). If sig. $<\alpha$ then is significant, so all independent variables in the model affect the dependent variable.

\section{$3.5 \mathrm{t}$ Statistics Test}

The $\mathrm{t}$ statistical test shows how far the influence of one explanatory variable/ independent individually in explaining the variation of the dependent variable (Ghozali, 2011), while the criteria for decision making if the value is sig. $\leq \alpha$, it is significant. Conversely, if the value of $\operatorname{sig}>0.05$, it is not significant.

\section{Reseult and Discussion}

Descriptive provides a general descripttion of the data and the distribution of the data used in this study. The description of the data in question includes the average value (mean), the highest value (maximum), the lowest value (minimum) and the standard deviation value describes the distribution of data in this study.

Table 1. Statistics Description of Data Research

\begin{tabular}{lrrrr}
\hline & \multicolumn{1}{c}{ Mean } & \multicolumn{1}{c}{ Max } & \multicolumn{1}{c}{ Min } & Std. Dev \\
\hline INF & 9.508 & 58.387 & 3.525 & 9.684 \\
GROWTH & 5.041 & 8.220 & -13.126 & 3.656 \\
INTEREST & 5.770 & 15.606 & -24.600 & 7.506 \\
GM2 & 19.021 & 62.762 & 4.761 & 11.809 \\
\hline
\end{tabular}

Based on Table 1 shows that the lowest inflation value reached $3.525 \%$, while the highest reached $58.387 \%$ occurred during the crisis. While the lowest economic growth occurred during the 1998 crisis which reached -13.126 and the highest reached 8.220. The interest rate has the lowest value of -24.600 and the highest is $15.606 \%$. The lowest money supply growth was $4.761 \%$ and the highest reached $62.762 \%$.

\subsection{Classical Assumption}

The classical Assumption test carried to get a model that is Best Linear Unbiased Estimate (BLUE). The concise results of the classical assumption test as Table 2.

Table 2. Result of Classical Assumption Test

Normality (Jarque berra)
Jarque-berra $=1,313513$; Prob $=0,518 * *$
Autocorrelation (Breusch-Godfrey)
Prob. Chi-square $=0,6805 * *$
Heteroscedasticity (White)
Prob. Chi-square $=0,8823 * *$
Linearity (Ramsey Reset)
Prob. F statistic $=0,0752 * *$
Multicollinearity
Growth $=2,122 * * * * *$
Interest rates $=2,025 * * * * *$
GM2 $=1,212 * * * * *$
Note: Ho accepted at Significance $* \alpha=0.01$,
$\quad * * \alpha=0.05, * * * \alpha=0.10 ; * * * *$ there is no
conclusion; $* * * * *<10$ or there is no
multicollinearity.


Results of the estimation model used in this study are using linear regression in brief as follows.

Table 3. Result of Research Model Estimation $\mathrm{INF}=15.86642+0.220006 \mathrm{GM} 2-2.075268$ Growth -0.014017 Interest $(0.0000) *(0.0008) *(0.000) *(0,9023)$

R-Squared $=0.897335 ;$ F-statistic $=78.66365$; sig. $\mathrm{F}=0.000^{*}$

Note: Significant at ${ }^{*} \alpha=0.01,{ }^{*} \alpha \alpha=0.05, * * * \alpha=0.10$; ( )parenthesis is a probability value

\subsection{Significant of $F$ test}

The results showed the value of Sig. F 0.000 $<0.001$ so Ho rejected. The condition shows that the regression model used in this research is feasible (Goodness of fit) to a regression model of hypothesis testing. So that simultaneously the money supply variable, economic growth and exchange rate affect inflation rate.

\subsection{Test of $t$ statistic}

The variable of money supply has a value of t statistic 3.796936>2.048, shows the influence of the money supply variable on inflation occurs in Indonesia, with a positive coefficient sign. The variable of economic growth has a value of $t$ statistic 8.720449>2.048, shows the influence of economic growth variables on inflation occur in Indonesia, with negative coefficient signs. The interest rates variable has a value of $t$ statistic $0.123814<2.048$, which shows there is no variable influence on interest rates on inflation occurs in Indonesia.

The amount of money in circulation and inflation is theoretically relevant to opinion (Mankiw, 2007) states that the current money supply determines the current price level. While empirically these results are in line with studies conducted by Ramady (2009), Habibi and Hidayat (2017), Salmanpour and Bahloli (2011), Nguyen (2015), Denbel, Ayen and Regasa (2016), Shah, Aleem and Arshed (2014), Agusmianata et al. (2018), concluded that money supply significantly affected inflation. However, this result is not in line with the study conducted by Lim and Sek (2015), who found that money supply has a negative influence on long-term inflation. Likewise, (Langi, 2014) found that the money supply had no effect against inflation. This means that based on the results the large amount of money in circulation will impact increasing inflation. This is also clear in the 1998 crisis, in which the movement of the money supply was accompanied by a movement in the value of inflation. This condition cannot be separated from concerns or be alert of the society so that a lot of money is held, which has an impact the increase in inflation occurred in Indonesia.

In sharia economics the occurrence of inflation caused by the money supply has a major impact on life, both on purchasing power and on the tendency to consume, where inflation ultimately causes poverty. Referring to the motive for money demand in conventional economic concepts, one of which is the motive of speculation. Speculation in sharia not permitted. That is, in order to prevent inflation, it is necessary to control the motives for the demand of money, especially for speculation.

Economic growth and inflation are theoretically relevant with the opinion of Frisdiantara, Mukhklis and Si (2016), states that high economic growth has an impact controlled inflation. While empirically these results are in line with the study conducted by Aurangzeb and Haq (2012), Lim and Sek (2015), Denbel, Ayen and Regasa (2016), Laryea and Sumaila (2001), state that economic growth has a negative effect on inflation. However, this result is not in line with the study conducted by Salmanpour and Bahloli (2011), states that economic growth has no effect on the inflation rate. Referring on the results can not be separated from the stability in the economy and the ability of the society to reach prices. Therefore, it is necessary to increase economic activity in a region which reflects the level of welfare of the community.

Interest rates and inflation empirically are not relevant to the opinion of Yodiatmaja (2012) states that interest rates ultimately affect inflation. Empirically the results are in line with the results 
of research by Langi (2014) shows that interest rates have no effect against inflation. It is not in line with previous studies Agusmianata et al. (2018), Nguyen (2015), Ramady (2009), Aurangzeb and Haq (2012), Habibi and Hidayat (2017), show a statistically significant interest rate on inflation. Likewise, with Olatunji et al. (2010), shows that interest rates negatively affect inflation. Although interest rates in research are not influential, it is important to remember that interest in the Islamic economy is unlawful (usury). This means that the impact of that is not only to make people poor but also to make the country threatened by its economy.

\section{Conclusions}

Based on the result of the study, it can be concluded that; (1) Money supply has a positive influence on inflation occurred in Indonesia, (2) Economic growth has a negative effect on inflation occurs in Indonesia, (3) Interest rates do not have an influence on inflation occurs in Indonesia.

\section{References}

Agusmianata, N., Militina, T., Lestari, D., \& Lestari, D. (2018). Pengaruh Jumlah Uang Beredar dan Tingkat Suku Bunga serta Pengeluaran Pemerintah terhadap Inflasi di Indonesia. FORUM EKONOMI, 19(2), 188. https://doi.org/10.29264/jfor.v19i2.2125

Arsyad, L. (2010). Ekonomi Pembangunan (5th ed.). Yogyakarta: UPP STIM YKPN.

Aurangzeb, \& Haq, A. U. (2012). Determinants of Inflation in Pakistan. Universal Journal of Management and Social Sciences, 2(4), 2340.

Awaluddin, A. (2017). Inflasi dalam Prespektif Islam (Analisis Terhadap Pemikiran ALMaqridzi). JURIS (Jurnal Ilmiah Syariah), 16(2), 197. https://doi.org/10.31958/juris.v16i2.973

Denbel, F., Ayen, Y., \& Regasa, T. (2016). The relationship between inflation, money supply and economic growth in Ethiopia: Co integration and Causality Analysis. International Journal of Scientific and Research Publications, 6(1), 556-565.
Retrieved from http://www.academia.edu/download/46046250/ijsrp-p4987.pdf

Frisdiantara, C., Mukhklis, S. I., \& Si, M. (2016). Ekonomi Pembangunan: Sebuah Kajian Teoretis dan Empiris (1st ed.). Malang: Lembaga Penerbitan Universitas Kanjuruhan Malang.

Ghozali, I. (2011). Aplikasi Analisis Multivariate Dengan Program IBM SPSS 19, cetakan kelima. In Badan Penerbit Universitas Diponegoro Semarang.

Gujarati, D., \& Porter, dawn C. (2010). Dasardasar Ekonometrika: Basic Economic. Jakarta: Salemba Empat.

Habibi, A., \& Hidayat, W. (2017). Analisis Pengaruh Economic Freedom Terhadap Foreign Direct Investment Di Negara ASEAN. Jurnal Ekonomi Pembangunan, 15(1), 87-100.

Karim, A. (2016). Ekonomi Makro Islam, Jakarta: PT. RajaGrafindo Persada.

Langi, T. M. (2014). Analisis Pengaruh Suku Bunga BI, Jumlah Uang Beredar, dan Tingkat Kurs Terhadap Tingkat Inflasi di Indonesia. Jurnal Berkala Ilmiah Efisiensi, 14(2).

Laryea, S. A., \& Sumaila, U. R. (2001). Determinants of inflation in Tanzania. Chr. Michelsen Institute.

Lim, Y., \& Sek, S. (2015). An examination on the determinants of inflation. Journal of Economics, Business and Management, 3(7), 678-682.

Mankiw, N. G. (2007). Makroekonomi. In Jakarta: Erlangga (6th ed.).

Nanga, M. (2005). Makroekonomi: teori, masalah dan kebijakan (2nd ed.). Jakarta: PT. Raja Grafika Persada.

Nguyen, B. (2015). Effects of fiscal deficit and money M2 supply on inflation: Evidence from selected economies of Asia. Journal of Economics, Finance and Administrative Science, 20, 49-53.

Olatunji, G. B., Omotesho, O. A., Ayinde, O. E., \& Ayinde, K. (2010). Determinants of inflation in Nigeria: A co-integration approach. 
Jurnal Ilmiah Ekonomi Islam, 5(02), 2019, 88

Parakassi, I. (2018). Inflasi dalam Perspektif Islam. Laa Maisyir: Jurnal Ekonomi Islam, 4(2), 41-58. Retrieved from http://journal.uin-alauddin.ac.id/index.php/lamaisyir/article/view/4420

Ramady, M. A. (2009). External and Internal Determinants of Inflation: A Case Study of Saudi Arabia. Middle East Journal of Economics and Finance, 2(1-2), 25-38.

Salmanpour, A., \& Bahloli, P. (2011). Inflation, inflation uncertainty and factors affecting inflation in Iran. World Applied Sciences Journal, 14(8), 1225-1239.
Shah, M. A. A., Aleem, M., \& Arshed, N. (2014). Statistical analysis of the factors affecting inflation in Pakistan. Middle-East Journal of Scientific Research, 21(1), 181-189.

World Bank. (2019). Indonesia | Data. Retrieved April 5, 2019, from The World Bank website:

https://data.worldbank.org/country/indonesia

Yodiatmaja, B. (2012). Hubungan Antara BI Rate dan Inflasi Pendekatan Kausalitas Toda-Yamamoto. Journal of Economics and Policy Jejak, 5(2), 117-229. 